\title{
Social Protection: Responding to a Global Crisis
}

\author{
Mark Davies and J. Allister McGregor
}

\begin{abstract}
The current global financial crisis will have adverse effects on poor people in developing countries in both the short- and long-term. While the complexity of this crisis makes its path difficult to predict, recent advances in social protection thinking and practice provide a body of experience for developing countries and development agencies to draw upon in responding to the crisis. Recognising that the crisis will produce pressures on national budgets and could lead to social and political unrest, this article argues that the ways that policymakers think about and design social protection responses will require careful consideration. It proposes a framework for prioritising responses and argues for an approach to designing social protection measures that take account of both immediate needs and the wider developmental role of social protection schemes. Social protection measures can be an important element in reconstructing a social contract that builds effective future governance for development.
\end{abstract}

\section{Introduction}

The current global financial crisis is impacting on developing countries and it will have adverse effects on poor people in the short run and across longer time-scales. It will also make others yet more vulnerable to poverty. This crisis is different from others that have impacted on developing countries over recent years: it is a compound crisis. It comes on the back of a period of food and fuel price volatility in many countries. It is also a crisis for developing countries amidst a global recession, which is of a greater scale than any witnessed in modern times, and as such, the global economy does not represent a ready source of dynamism to draw developing countries out of their crisis. The compound nature of this crisis will make its path difficult to predict, but this does not mean that we do not know how development policy might effectively respond to it.

The last two decades have witnessed the emergence and growth of social protection policies and programmes as a component of development strategies that better enable vulnerable people to cope with the crises and setbacks that characterise the development process for many developing societies. As different developing countries have been affected by one form of shock or another, there have been substantial advances in understanding how programmes which are focused on protecting the poorest can be designed and implemented to mitigate against their most damaging effects.

Social protection has grown because of the recognition of the high human costs and structural and transitional disruption that the development process brings (Cornia et al. 1987). These human costs also relate to the political costs of development and there is increasing recognition that developmental volatility, which disrupts peoples' lives, is also a source of political instability which can be corrosive for national governance and ultimately can have global ramifications (Nelson 1990). Our accumulated knowledge of the harm that can be inflicted by the ups and downs of development processes suggests that it is not a question of whether we can afford to support social protection initiatives during this crisis; rather, the real political question is whether we can afford not to.

In this article, we will consider the ways in which this crisis is likely to affect vulnerable people and consider how social protection thinking offers possible responses to this. The fiscal 
circumstances that will prevail mean that a prioritisation of development efforts will be required. We recommend a framework for prioritising social protection responses and review a range of evidence on how social protection programmes have been developed and worked in selected developing countries during recent crises. We conclude by summarising key lessons learnt and discussing some of the ways in which the international community might support the ownership and development of effective, national social protection responses to this crisis.

\section{Crisis and social protection responses}

This current crisis is different from other crises that have impacted on developing countries in recent years (e.g. the East Asian Crisis of 1997; the Mexican Peso Crisis of 1994) in two important ways. First, it is a global recession. This means that developing countries have fewer options to cope with this crisis by virtue of their relationships with healthier parts of the global economy. And second, it is impacting at a time when many developing countries have been experiencing volatility in prices for food and fuel (see Hossain, this IDS Bulletin). For many vulnerable people in developing countries, this volatility in food and fuel prices is already regarded as a crisis and as such, the impacts of the global financial recession make this a compound crisis.

The global nature of this recession leads to the initial observation that coping with this crisis will be more difficult than has been the case in others recently experienced by developing countries because they have occurred while other parts of the global economy has remained in good health. But before considering the role of formal social protection measures, it is important to remind ourselves that the first way in which most people in developing countries protect themselves from poverty and vulnerability is through their own work and efforts as part of their broader livelihood strategies. Three aspects of livelihoods strategies that we know are important in developing countries and for poor people will be particularly affected by the global character of this crisis. These are: remittances from international migration; employment of unskilled labour in activities that are financed by foreign direct investment (FDI); and incomes and employment from the international tourism sector. ${ }^{1}$
Remittances from international migration have grown in significance for many people in developing countries over recent decades. In some countries such as Bangladesh, Uganda and the Philippines, these constitute an important flow of income for the country generally and for some households in particular. A recent IMF report indicates that, with the onset of this crisis, remittance levels stopped growing in 2008 and it projects that remittance levels will shrink from 2009 onwards (IMF 2009). The same report estimates that the level of Foreign Direct Investment will drop by 20 per cent in 2009 compared with 2008 levels. It is difficult to predict when FDI will recover for developing countries. This decline will affect those developing countries that are hosts of manufacturing bases for international markets and as well as those where FDI is an important factor in primary commodity production or extraction. There are widespread reports of the tightening of foreign direct investment resulting in cutbacks in production and employment and the suspension of planned initiatives (IMF 2009).

A range of other developing countries have come to rely significantly on revenues from international tourism, and in past crises (e.g. the South-east Asian crisis of the 1990s) this sector remained buoyant and was an important alternative source of jobs and incomes (Lee and Rhee 1999). The global nature of this crisis is already witnessing falls in international travel and pressure on international airlines. A recent report from IATA (International Air Transport Association $)^{2}$ indicates that the figures for January 2009 showed the fifth consecutive month of contraction in international passenger demand, which fell by a further 5.6 per cent in that month alone. As such, it cannot be expected that in this crisis the international tourism sector in developing countries will provide the same buffer against declines in other parts of their economy as it has previously.

\section{The role of social protection}

But as the crisis bites, the pressures on public budgets will increase and with it so will the competition and arguments about how scarce public resources should be allocated.

Given the deterioration of the economic conditions within which people in developing countries are able to protect themselves from 
their vulnerability and poverty, public action both to head off the immediately damaging effects of the crisis and to stop the crisis from eroding the foundations for future successful development becomes all the more significant. Social protection is a useful way of describing a range of policy interventions which protect the vulnerable against livelihood risks. These interventions can take a variety of forms from social assistance, to social insurance, to labour market regulation. Social protection can be provided by the state or by non-state bodies, but because of the scale of this crisis and that it is of political significance as an element of the social contract between citizen and state, the emphasis here is on social protection as a nation-state responsibility. This focus is further justified by recognition that social protection measures must often seek to work at a systemic level and beyond the material dimensions of peoples' lives, seeking to address the protection and enhancement of the human rights and social status of marginalised groups and individuals (Devereux and Sabates-Wheeler 2004).

The ways that this crisis will impact on developing countries will differ between countries. Contradicting initial speculation, it is apparent that it will affect all developing countries regardless of the extent of their integration into the formal global economy. And, even where the quantum of effect in terms of macroeconomic indicators appears small, which it may well do in the case of some African countries, its impact in terms of the costs to particular human beings is still likely to be high. The impacts will differ both in terms of what groups of people the burden will particularly fall upon and also in the ways that it will affect different groups over time. This means that social protection responses will need to be tailored and calibrated to the particular crisis outcomes and the fiscal conditions of the country impacted. But as the crisis bites, the pressures on public budgets will increase and with it so will the competition and arguments about how scarce public resources should be allocated. In this context, a first important step in considering how to respond to the crisis is to have a transparent and logical framework with which to consider how to prioritise possible social protection initiatives. The basis for such a framework was suggested by Ravallion and Lokshin (2000) in their analysis of earlier crises and it can be adapted here for use at this time. There are three key levels that must be considered to guide the prioritisation of social protection responses in each nation-state context:

1 The vulnerability characteristics of the structure of the economy:

\section{Which sectors of the economy are particularly vulnerable to shocks transmitted from the global economy (e.g. openness to trade, dependence on foreign direct investment, dependence on remittances, financial sector dependence on international banks)?}

2 The distribution of vulnerabilities across different sections of national populations:
Which groups of the population will be most affected by these shocks and among these, which groups are particularly vulnerable to adverse effects from the shocks (e.g. those with no employment alternatives; dependent on falling demand for products; with limited savings or access to credit)?

3 The pathways of adverse developmental effects through vulnerable households to individuals:

\section{How will vulnerable households be particularly affected by the impact and how might we expect them to attempt to cope with the shock (e.g. will it be through the reduced availability of incomes, or food, or agricultural inputs; will shortfall in food or incomes be equally shared or will it result in some family members bearing more of the brunt of the shortfall than others)?}

The current understanding is that this crisis will hit quickest and hardest in those countries that have been most dynamically engaged with the global economic system. So, ironically, we might expect that those developing countries which have been experiencing the greatest forward momentum recently and which have created systemic openness in order to connect to world financial and trade systems to be those which will be most quickly affected. However, it is predicted that the crisis will transmit through second order effects and over slower time-scales even to those developing countries and those people not so strongly connected to the global economy. At whichever speed the crisis impacts, the lesson from previous crises, including the last major global recession in 1929, is that it translates into disproportionately bad social outcomes for the poor (Rothermund 1996: 
Table 1 The role of social protection in crises

\begin{tabular}{|c|c|c|c|}
\hline Timeframe & Type of social protection & Social protection instruments & Role in this crisis \\
\hline \multirow[t]{4}{*}{ Short-term } & Protective (social assistance) & $\begin{array}{l}\text { - Social transfers } \\
\text { - Disability benefit } \\
\text { - Pension schemes } \\
\text { - Social services }\end{array}$ & $\begin{array}{l}\text { Immediate protection and } \\
\text { relief from poverty and } \\
\text { deprivation }\end{array}$ \\
\hline & $\begin{array}{l}\text { Preventive (Insurance and } \\
\text { diversification mechanisms) }\end{array}$ & $\begin{array}{l}\text { Social transfers } \\
\text { Social insurance (pensions, health } \\
\text { insurance, unemployment benefit) } \\
\text { Livelihood diversification } \\
\text { - Savings clubs; funeral societies }\end{array}$ & $\begin{array}{l}\text { Prevents damage to } \\
\text { coping strategies }\end{array}$ \\
\hline & $\begin{array}{l}\text { Promotive (economic } \\
\text { opportunities) }\end{array}$ & $\begin{array}{l}\text { - Social transfers } \\
\text { - Access to credit } \\
\text { - Asset transfers/protection } \\
\text { - School feeding } \\
\text { - Starter packs } \\
\text { - Access to common property resources } \\
\text { - Public works programmes }\end{array}$ & $\begin{array}{l}\text { Promotes resilience } \\
\text { through livelihood } \\
\text { diversification and } \\
\text { improves security }\end{array}$ \\
\hline & $\begin{array}{l}\text { Transformative (addressing } \\
\text { underlying social vulnerabilities) }\end{array}$ & $\begin{array}{l}\text { - Promotion of minority rights } \\
\text { - Anti-discrimination campaigns } \\
\text { - Social funds }\end{array}$ & $\begin{array}{l}\text { Transforms social } \\
\text { relations to reduce } \\
\text { exclusion }\end{array}$ \\
\hline
\end{tabular}

11-14). The experience of more recent crises in developing countries also indicates that both women and children are likely to suffer badly from their effects (Oxfam 2007; Moser and Felton 2007; Sumner and Wolcott, this IDS Bulletin). A review of these past crises indicates that shocks have immediate effects on the poor, through food prices, credit and unemployment, but also over the longer run, they generate new forms of vulnerability across the population and in doing so, lay the foundations for future generations of poverty.

\section{How can social protection respond to this financial crisis?}

Samson (2009) identifies four ways in which social protection interventions can help address the crisis and underpin other investments in development:

- First, they constitute effective instruments for reducing poverty and destitution in many countries.

- Second, by supporting consumption by the poor, they complement macroeconomic policies aimed at tackling the contractionary impacts of the crisis.
- Third, by maintaining and building human capital and reducing social risk, they promote long-term human capital development, livelihoods, employment and economic growth.

- Fourth, by providing poor people with a stake in the economy, they promote social cohesion and facilitate the implementation of other necessary reforms.

We know this because, over the last decade the growth in the number of social protection programmes around the world has generated a substantial body of evidence about what social protection can do and how it can do it (see Box 1). These case studies demonstrate how social protection can both cope with different forms of crisis and have positive developmental effects.

The analysis of these and other social protection interventions suggests four types of role that social protection programmes and policies can play. These roles are Protection, Prevention, Promotion and Transformation (Devereux and Sabates-Wheeler 2008). Using this in conjunction with the prioritisation framework above, this broad and comprehensive view of social protection enables us to consider how social 


\section{Mexico - Oportunidades}

The Oportunidades Program in Mexico, which was formerly the PROGRESA Program, is now the centrepiece of Mexico's targeted poverty reduction strategy (Britto 2008). It provides cash and in-kind transfers conditional on school attendance and regular visits to health centres. In rural areas, Oportunidades is reported as having increased education achievement by 14 per cent and in relation to nutrition, children on the scheme have experienced higher growth than average and lower levels of anaemia than children not on the scheme (Garcia 2004). In terms of health, Oportunidades is credited as having boosted demand by women for antenatal care by 8 per cent, and contributed to a 25 per cent drop in the incidence of illness in newborns and 12 per cent lower incidence of ill-health among under five-year-olds compared with non-PROGRESA children (Skoufias and McClafferty 2000).

\section{Ethiopia - The Productive Safety Net Programme}

In Ethiopia, the Productive Safety Net Programme (PSNP) was launched in January 2005 and now provides regular cash or food transfers to more than 8 million chronically foodinsecure people in 290 woredas (districts) through a combination of public works and direct assistance. The 2008 evaluation of the PSNP found that:

- Cash and food transfers made a significant positive contribution to food security and in helping recipient households meet basic needs.

- Cash transfers are used for investment and asset accumulation as well as consumption. Investment in education is the most common form, followed by investment in farming, debt repayment, healthcare and micro-enterprises. Some cash recipients also had purchased additional assets such as small livestock.

- Real incomes of PSNP beneficiaries have been estimated to have increased by more than 50 per cent between 2006 and 2008, while real incomes of comparable nonbeneficiaries fell by 20 per cent over the same period (Devereux et al. 2008).

\section{Bangladesh - BRAC's Ultra-Poor Programme}

In Bangladesh BRAC's Ultra-Poor Programme has focused on the most vulnerable groups of the poorest for whom crisis is a common occurrence. As part of BRAC's wider efforts in their 'Challenging the Frontiers of Poverty Reduction Programme' this initiative seeks to build-up the productive asset base of the poorest households and individuals that have often been seen as beyond the reach of traditional poverty focused initiatives. It is estimated as having resulted in around 85,000 women graduating out of this 'ultra poor' status. There is persuasive evidence of the programme's contribution to a reduction in extreme poverty among poor Bangladeshi women. Increased earnings from skill-based productive activities were observed among 90 per cent of targeted households, with income growth between 2002 and 2005 varying from 40-56 per cent. The 'Ultra-Poor' programme is also reported as having resulted in an increase in primary school enrolment rates among children of targeted ultra-poor households of more than 400 per cent between 2002 and 2005 (Young 2003).

protection measures might be focused and designed to address different consequences of the crisis and in relation to different time-scales of its effects (see Table 1).

Protection measures provide relief from deprivation and include traditional safety net instruments, social assistance and social services for poor individuals or groups who need special care. Preventative measures seek to prevent deprivation and deal directly with poverty alleviation. They include social insurance for people who have fallen, or might fall into poverty and can include formal systems and informal mechanisms, such as savings clubs and funeral societies. The longer-term dimensions of the 
impacts of crisis can be addressed through promotive measures, which seek to enable longerterm enhancements to peoples' livelihood strategies, and transformative forms of social protection, designed to address the underlying social structures that are at the root of social vulnerabilities and which are exposed by crisis. Each role can be fulfilled by different policy instruments and each could address different aspects of the current crisis.

\section{The politics of crisis and social protection: moments of opportunity or decline}

Historically, times of economic crisis also result in social and political unrest. In some circumstances, where political leadership is strong, this has proven to be a key driver in the development of social protection schemes (e.g. the New Deal in post-depression USA); in others, it can provoke political paralysis and the shrinkage of state protection, which triggers a spiral of long-term decline (e.g. the political failure to address chronic food insecurity in Ethiopia after the 1984 famine).

Social protection systems, both formal and informal, contribute one of the foundational elements of the social contract that binds people to those that would govern them. When these fail in times of crisis then it is to be expected that those who are able to politically mobilise will do so to protest against the failure of their governors to keep their end of the bargain. As the ultimate backers of all systems of social protection in a nation state (see McGregor 1989) it is also to be expected that it will usually be the government that is the focus of protest and against whom anger is directed.

In such circumstances, governments can either use force to suppress protest or find ways of ameliorating the immediate causes of unrest. The suppression of protest usually contributes to the worsening of the conditions of governance in any society, while some ways of ameliorating problems can be little more than temporarily buying-off the protestors or their organisers. A key lesson from recent crises in developing countries suggests that social protection responses to social and political unrest can represent a window of opportunity and that it is important to recognise that the difficulty of crisis can also be seized as moments for progressive development initiative.
The establishment of progressive social protection arrangements can not only be perceived as a direct way of dealing with crisis, but as part of longer term efforts to reduce poverty which positively contribute to the construction of effective governance for development. The design of social protection interventions at times of crisis thus must seek to avoid focusing solely on the short-term manifestations of the crisis and be conceived of as a potentially fundamental contribution to the rebuilding of a social contract for effective development.

A human wellbeing perspective provides us with a distinctive way of viewing social protection schemes at this time (McGregor 2007). The wellbeing perspective argues that the purpose of effective development is to establish the societal conditions in which different human beings in a given society can reasonably and sustainably expect to achieve wellbeing. By not only addressing the immediate manifestations of poverty at a time of crisis but also by reducing vulnerability and insecurity, social protection schemes can be viewed as representing a key element of the social infrastructure upon which successful development can build. Effective national social protection schemes constitute an important element of the societal conditions for human wellbeing.

Recognising that human wellbeing is not 'given' to people by governments or development agencies but is achieved by people themselves (McGregor 2009), this perspective also then provides us with some basic guidelines as to what must be borne in mind when designing social protection mechanisms at this time. The first is that even in an emergency context they should be designed so as consciously to avoid social protection as charity, or as a mechanism for inducing dependency. Rather, they must be conceived of in a more political way as part of the design of an enabling set of conditions within society, within which people are better able to achieve their own notions of wellbeing. In efforts to promote livelihoods, for example, evidence from programmes such as the PSNP in Ethiopia have demonstrated that when designed correctly, the predictable, timely provision of resources provides beneficiaries with greater opportunities to invest or take risk. If an objective of transformative social protection is to address 
social vulnerability to 'transform society' then the design of cash transfer programmes can potentially have wider, transformational effects. Technocratic approaches to cash transfer designs can serve to obscure the potential role of social protection mechanisms as a means of empowerment. Beyond their instrumental importance social protection programmes can be conceived of as being about reconstructing citizenship and as a contributing element to building effective nation-state governance.

Of course the strength of political leadership in times of crisis depends in large part on the scale of resources that the government can draw upon and, as we have noted above, a likely upshot of this global crisis is that there will be fiscal strain on developing country governments. Not all developing countries can afford the social protection measures that are important at this time, and thus supporting governments under stress becomes a key challenge for the global development community. As the 2009 G20 communiqué indicated, a key potential role of foreign assistance in the coming years will be to focus funding on governments so that they are able to institute social protection measures as a means of protecting the vulnerable. We add here however, the caveat that this funding mechanism should also have in the forefront of its thinking the promotion of national ownership of public social protection schemes that can contribute to stable and potentially progressive governance arrangements and which will provide a platform for the vulnerable and insecure to participate meaningfully in their societies.

The Indonesian Government response to the financial crisis in the 1990s provides a useful example to illustrate this argument. The financial crisis of 1997 caused the poverty rate in Indonesia to double in a year, but the Government of Indonesia (GoI) responded quickly by introducing a National Safety Net programme. The subsequent results of the programme have been impressive with the poverty rate reducing from 33 per cent in 1998 to 12 per cent in 2002. Evidence suggests that without this programme the broader economic recovery that Indonesia has experienced over this period would not have been possible (Pritchett et al. 2003).

The success of the programme demonstrates the possible benefits from responding quickly and with a clear sense of purpose. The GoI, without previous experience of implementing a safety net programme, learnt about, improved and expanded the programme as they went along (Sumarto 2008). This enabled them to respond to the immediate effects while developing a more effective long-term response. The government gradually became more ambitious in both the objectives and scale of their social protection programmes as they became more experienced, culminating in the launch, in 2005 of an unconditional direct cash transfer programme and in the conditional cash transfer programme in 2007.

In Mexico, there was a different pace of response but that example demonstrates the political dynamics of the issue and illustrates a case of building a strong constituency for social protection through the accumulation of evidence. In 1997, after a period of indecisive responses to the financial crises in 1994 (see Attanasio and Szekely 2004), the Government of Mexico introduced the PROGRESA Program. The PROGRESA Program has since grown and transformed into Oportunidades and it has a range of objectives which focus on improving the educational, health, and nutritional status of poor families, and particularly of children and their mothers. Although, because of the extent of political reluctance over the programme, this initiative started out on a modest scale, by 2002 Oportunidades was reaching over 25 million people across Mexico. As noted above, it is now regarded as the centrepiece of Mexico's poverty reduction strategy (Skoufias 2005). The key to its expansion and success has been its use of evidence of impact. As well as bolstering public support, this evidence has been an important factor in persuading politicians and donors to continue supporting and expanding the programme. A strong constituency for social protection has been developed over time, but this has been led from the front by high level political ownership on behalf of successive governments (de Britto 2008).

In addition to recognising the positive social protection responses that have emerged from previous crises, we also need to note that that it is also possible to make things worse. The World Bank's (2005) review of social protection responses to the Central American coffee crisis of 1997-2001 suggests that governments overfocused on the short term (and particularly on 
restructuring farmers' debts), and in doing so these measures blocked the reform of what was an inefficiently organised sector. This, the report suggests, had the consequence of prolonging the crisis. On the other hand, preventative and socially progressive protection measures, such as public employment programmes which were more effective at preventing people falling into poverty, were relatively under-funded at that time. The World Bank study illustrates how major government interventions in crisis can be regressive where they focus on the short run at the expense of considering how these relate to longer run impacts on the roots of vulnerability.

Finally, while these examples demonstrate how established social protection systems can provide an important safety net when crisis strikes, we can also consider a case where an absence of publicly sponsored social protection is regarded as having worsened the impact of economic downturn and disruption. At that time of the 1990s crisis Korea's system of social protection was largely private enterprise based and when production adjusted to lower international demand, the workers who were laid off (generally the least educated and qualified) had no public social safety-nets to fall back on. At the same time, government spending on education fell from 5.1 per cent of GDP to 4.0 per cent, between 1996 and 1998 (Gottschalk 2004). The lack of an adequate public social protection system at the time of the 1990s crisis resulted in considerable hardship and the human costs of the crisis in terms of increased poverty and inequality were high (Lee and Rhee 1999; Lin 2008).

\section{Conclusion - social protection for crisis and beyond}

In this article we contend that social protection policies and measures represent a potentially effective and progressive way of responding to the current compound crisis that is impacting on developing countries. Recent experience suggests that countries that have national social protection programmes in place are likely to be in a better position to cope with crisis. ${ }^{3}$ Others that have small-scale social protection pilot programmes ${ }^{4}$ have some capacity that can be built upon. We argue that low income countries that do not have social protection programmes should be supported to develop them as quickly as possible as a means of coping with this crisis (Samson 2009).
However, in all of these cases we argue that the design of social protection schemes should not focus solely on addressing the immediate impacts of the crisis but be conceived of in relation to the longer-term development of the countries concerned. It is certainly the case that such measures must address the immediate deprivations that result from the crisis, but this should not be the sole criteria guiding programme design. In the design and implementation of social protection programmes, it is important to look beyond the current crisis and in doing so, broaden our objectives. If we consider social protection objectives in relation to the categorisation of 'protection, prevention, promotion and transformation' then our ambitions should begin with 'protection' but then extend to consider these wider possible roles of social protection.

We have argued that it is necessary to learn from the accumulated body of recent experience in how to design social protection schemes but warn against a technocratic approach to social protection in response to crisis. The politics of social protection in times of crisis are particularly acute and critical. It is to be expected that many poorer developing country governments will come under political pressure, in some cases manifested in social unrest, and that they will face moments where they can act progressively or regressively in response to crisis. We argue here that there are sound developmental reasons for the international community to act in ways that enable and support developing country governments under stress to act progressively.

A human wellbeing perspective on social protection provides us with some new ways of framing the argument for social protection. It points to the place of social protection schemes at the heart of the social contract between citizens and their governments. As such, successful social protection responses that are set in place in times of crisis, but which are built to last beyond the crisis, can be conceived of as representing a more fundamental development project. They represent a means of building the societal conditions within which people, and particularly poorer and more vulnerable people, might reasonably seek to achieve their wellbeing. The creation of such societal conditions provides a basis for effective governance. 
The forms of support that the international community can give to develop social protection responses to the current compound crisis are multifold, but the foregoing argument emphasises the need for this to be supportive of domestically driven social protection policy process based on the realities of national policymaking processes.

Central to achieving social protection at scale are two interlinked elements - knowledge and political commitment. During this crisis, in comparison with previous financial crises, knowledge on the impact of social protection gained through existing programmes provides us with a much greater sense of what works when, where and why. For political leadership in developing countries to be supported at this time and to institute progressive social protection measures at this time, a number of forms of support are required. The first and most easily recognised is for financial assistance so that social protection is enabled at a time when fiscal tightening makes it difficult to respond to the many demands that will fall on public budgets in a time of crisis. The second form of support is in terms of the experience of designing effective social protection schemes which can then be monitored in order to generate evidence of their effect. Finally, the third form of support is the

\section{Notes}

1 We do not discuss here possible declines in the prices of primary products either as a general result of global recession or increased protectionism.

2 See: www.iata.org/pressroom/pr/2009-02-2601.htm (accessed 3 July 2009).

\section{References}

Attanasio, O.P. and Szekely, M. (2004) 'Wage Shocks and Consumption Variability in Mexico During the 1990s', Journal of Development Economics 73: 1-25

Cornia, G.A.; Jolly, R. and Stewart, F. (eds) (1987) Adjustment with a Human Face: Protecting the Vulnerable and Promoting Growth, Oxford: Oxford University Press

De Britto, T. (2008) 'The Emergence and Popularity of Conditional Cash Transfers in Latin America', in A. Barrientos and D. Hulme (eds), Social Protection for the Poor and Poorest, Basingstoke: Palgrave Studies in Development provision of a coherent argument as to why social protection should be instituted at this time and why it should be designed with not only immediate responses in mind but with their longer-term development potential to the fore. The examples that we have cited from Indonesia and Mexico provide some good insights into the political benefits of such an approach.

The commitments highlighted in the G20 London Summit (2009) Communiqué and discussion of financial support to social protection through global vulnerability funds provides a sense of global responsibility and cooperation around a social protection agenda. In translating these commitments into action, social protection should follow this path with responsibility for developing national programmes transcending national boundaries. Although responsibility for this ultimately lies nationally, interest should be shared internationally. Instead of individual responses implemented in isolation, we make a call for global partnership. Central to this is the sharing of experience, of evidence, of ideas and of political support for initiatives. This form of global partnership provides us with real opportunities to make more permanent change through social protection both for this and future financial crises.

3 Countries include: Ethiopia, Ghana, Kenya, Lesotho, Mongolia, Nepal, Pakistan and Vietnam (Samson 2009).

4 Countries include: Malawi, Senegal, Tanzania, Uganda and Zambia (Samson 2009).

Devereux, S. and Sabates-Wheeler, R. (2008) 'Transformative Social Protection: The Currency of Social Justice', in A. Barrientos and D. Hulme (eds), Social Protection for the Poor and Poorest, Basingstoke: Palgrave Studies in Development

Devereux, S. and Sabates-Wheeler, R. (2004) Transformative Social Protection, IDS Working Paper 232, Brighton: IDS

Devereux, S.; Sabates-Wheeler, R.; Slater, R.; Tefera, M.; Brown, T. and Teshome, A. (2008) Ethiopia's Productive Safety Net Programme (PSNP): 2008 Assessment Report, Addis Ababa: PSNP Donor Coordination Group, December 
G20 London Summit (2009) Leaders Statement, Thursday 2 April, Guardian, www.guardian.co.uk/world/2009/apr/02/ g20economy (accessed 18 May 2009)

Garcia, R. (2004) External Evaluation of the Impact of the Oportunidades Human Development

Programme, Cuernavaca: Instituto Natzional De Salud Publica

Gottschalk, R. (2004) How Financial Crises Affect the Poor, report for Department for International Development, Economist Resource Centre, London

IMF (2009) The Implications of the Global Financial Crisis for Low-Income Countries, Washington DC: IMF

Lee, J. and Rhee, C. (1999) Social Impacts of the Asian Crisis: Policy Challenges and Lessons, Occasional Paper 33, UNDP, http://hdr.undp.org/docs/publications/ocational _papers/oc33ahtm (accessed 1 June 2009)

Lin, J.Y. (2008) The Impact of the Financial Crisis on Developing Countries, Seoul, Korea: Korean Development Institute, http://siteresources. worldbank.org/DEC/Resources/847971104785060319/598886-1104852366603/ 599473-1223731755312/Oct 31 JustinLin KDI_remarks.pdf (accessed 1 June 2009)

McGregor, J.A. (2009) Wellbeing and International Development Policy and Practice, briefing paper to Wellbeing to Policy workshop, IDS, Sussex, February

McGregor, J.A. (2007) 'Researching Human Wellbeing: From Concepts to Methodology', in I.R. Gough and J.A. McGregor (eds), Well-Being in Developing Countries: From Theory to Research, Cambridge: Cambridge University Press

McGregor, J.A. (1989) 'Towards a Better Understanding of Credit in Rural Development. The Case of Bangladesh: The Patron State', Journal of International Development 1.4: 467-86

Moser, C. and Felton, A. (2007)

'Intergenerational Asset Accumulation and Poverty Reduction in Guayaquil Ecuador (1978-2004)', in C. Moser (ed.), Reducing Global Poverty: The Case for Asset Accumulation, Washington DC: Brookings Press
Nelson, J.M. (ed.) (1990) Economic Crisis and Policy Choice: The Politics of Adjustment in the Third World, Princeton: Princeton University Press

Oxfam (2007) Debt and Women, Jubilee Debt Campaign Briefing, www.oxfam.org.uk/ resources/policy/debt_aid/downloads/ jubilee_debt_women.pdf (accessed 1 June 2009)

Pritchett, A.; Sumarto, S. and Suryahadi, A. (2003) Targeted Programs in an Economic Crisis: Empirical Findings from Indonesia's Experience, BREAD Working Paper 030

Ravallion, M. and Lokshin, M. (2000) Short-Lived Shocks with Long-Lived Impacts?' Household Income Dynamics in a Transition Economy, World Bank Policy Research Working Paper 2459, http://econ.worldbank.org/external/default/ main?page $\mathrm{PK}=64165259$ \&piPK $=64165421$ \& theSitePK $=469372 \&$ menuPK $=64216926 \&$ entityID=000094946_00102201364666 (accessed 1 June 2009)

Rothermund, D. (1996) The Global Impact of the Great Depression, 1929-1939, London: Routledge

Samson, M. (2009) The Implications of the Global Financial Crisis for Low-Income Countries, Cape Town: Economic Policy Research Institute

Skoufias, E. (2005) PROGRESA and Its Impacts on the Welfare of Rural Households in Mexico, International Food Policy Research Institute, Research Report 139, Washington DC: IFPRI

Skoufias, E. and McGlafferty, B. (2000) Is PROGRESA Working? Summary of the Results of an Evaluation by IFPRI, International Food Policy Research Institute 118, Washington DC: IFPRI

Sumarto, S.; Suryahadi, A. and Bazzi, S. (2008) 'Indonesia's Social Protection during and after the Crisis' in A. Barrientos and D. Hulme (eds), Social Protection for the Poor and Poorest, Basingstoke: Palgrave Studies in Development Young, R. (2003) BRAC Challenging the Frontiers of Poverty Reduction: Targeting the Ultra Poor Targeting Social Constraints, Monitoring Review 2003, independent review, Dhaka: DFID 